\title{
'Drop-out' row hits soft spot for UK universities
}

London. A row over disputed university 'drop-out' rates published last week has highlighted the problems faced by science, engineering and technology students, who are more likely to fail than their peers studying arts and social sciences.

Figures published in The PUSH Guide to Which University, a rough guide aimed at helping prospective students to choose a university, show that in some UK universities as many as 1 in 5 students fail to graduate. According to the figures, the average drop-out rate for students expected to graduate in 1992 was 13.2 per cent.

The PUSH 'league tables', which are calculated using statistics from the Committee of Vice-Chancellors and Principals (CVCP) and the Universities Funding Council (UFC), have been attacked as inaccurate by some of the universities singled out. But even if some of the figures are wrong, the guide has succeeded in drawing attention to a mounting problem which many in the universities would rather keep under wraps.

An earlier study of Scottish universities confirmed anecdotal evidence that the highest non-completion rates are in engineering and other subjects with higher-than-average numbers of hours spent in the laboratory or lecture room. The study was funded by the Scottish Office Education Department to find out why the rate was 4 per cent higher in Scotland than in the rest of the United Kingdom.

Robin Knops, professor of mathematics and vice principal of Heriot-Watt University in Edinburgh says that his university has taken steps to address the problem since the Scottish Office report came out. He thinks that the difficult ideas and concepts in- volved in science, engineering and technology subjects have combined with an overloaded syllabus and all the normal pressures of student life to aggravate the problem.

The PUSH guide lists Kings College London, part of the University of London, as having a drop-out rate of 21.3 per cent, second highest in the 'league'. But the college says the correct figure is 14 per cent.

A spokesman for the London School of

\section{IMAGE UNAVAILABLE FOR COPYRIGHT REASONS}

\section{More students in - fewer out?}

Economics (LSE) says that the college is "very, very annoyed" that PUSH has released figures into the public domain that the LSE says are wrong. PUSH calculates drop-out rates for LSE to be 19.4 per cent, but LSE says the true rate was 7.9 per cent in 1992

According to the CVCP, which commissions the Universities Statistical Record to compile statistics annually, using them to create league tables is likely to be "misleading" because of the different subject and student mixes of the institutions. A CVCP spokesman said that the national success rate of 87 per cent for $1992-93$ was something that the country "should be proud of".

At the University of Salford, Les Kilby, senior assistant registrar, says the university's unusual mix of courses tends to inflate its non-completion rate. Salford runs a high proportion of ' $2+2$ ' courses, where students with one A-Level can study for two years at an associated college for a diploma before deciding whether to study for a degree. Although all are registered at Salford as degree students, many successfully complete the first two years but decide not to continue. Once these courses are taken into account, Salford calculates its noncompletion rate as 16 per cent compared to the 26.1 per cent quoted by PUSH.

Others, such as Brunel University on the outskirts of London and Heriot-Watt, accept that the PUSH figures of 21 per cent and 20.3 per cent respectively are about right. A Brunel spokesman says the dropout rate is a "matter of concern" and that it is conducting an internal analysis of the reasons. Both Brunel and Heriot-Watt point to the very high proportion of students studying science, technology and engineering subjects at their institutions.

According to the latest edition of the CVCP/UFC management statistics, the percentage of successful leavers is 86 per cent for physical sciences and 83 per cent for engineering and technology. That compares with 90 per cent for social studies, humanities and business administration.

Knops is confident that the measures introduced at Heriot-Watt can stem the tide of non-completions. They include a compulsory mentor scheme for each student, remedial teaching and support for any student identified as struggling and a modular course structure with students being examined at the end of each module rather than at the end of the year.

\section{State of Washington plans cull to save endangered steel-}

San Francisco. Environmentalists and government officials in the northwest United States are at odds over a plan to protect an endangered breed of fish by killing off the highly popular sea lions that feed on them.

The state of Washington has asked the federal government for permission to "fatally remove" about half-a-dozen California sea lions that are ambushing wild steelhead trout on their way to spawn. Both species are protected by federal law.

In a letter to the Secretary of Commerce, Ron Brown, the state has called for a task force to rule whether killing the sea lions is justified - a first step the state must take, under law, before going ahead with the cull. Environmentalists hope that a less drastic solution can be found. "We are trying to find ways to make the fish less vulnerable," says Julia Reitan of the Seattle section of the Sierra
Club, an environmental pressure group.

That something needs to be done is indisputable: last year only about 70 of the

THE MOTION PICTURE THAT EVERYONE'S TALKING ABOUT!

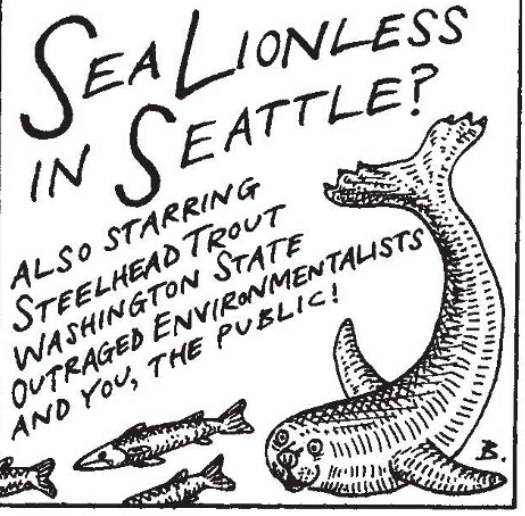

steelhead, a popular and beautiful food fish, reached their spawning ground. This contrasts with 2,965 known fish in 1986 and is far below what is needed to sustain the species.

The fish, an anadromous form of rainbow trout, swim from the salt water of Puget Sound to Lake Washington on their way to spawn in the Cedar River. Their way is blocked by the Ballard Locks, where the waterway narrows. Sometime around 1980, a pod of approximately 60 sea lions began waylaying the steelheads at the locks. Of those sea lions, about five or six are particularly accomplished hunters - - and these are the target of the proposed cull.

Unlike most acts of depredation, which usually take place in remote areas, the sea lions attack the steelhead in downtown Seattle, where the spectacle has become a popular tourist attraction. 